Journal of

Women's Health and Gynecology

\title{
Postnatal Care Utilization and Its Determinants in Loma District, Southwest Ethiopia: A Community Based Cross Sectional Study
}

\section{Teklemariam Ergat Yarinbab ${ }^{1^{*}}$, Wosen Chemesse Tona ${ }^{2}$}

${ }^{1}$ Department of Public Health, College of Health Sciences, Mizan-Tepi University, Ethiopia

${ }^{2}$ Department of Epidemiology, College of Health Sciences, Jimma University, Ethiopia

${ }^{\star}$ Corresponding author: Teklemariam Ergat Yarinbab, Department of Public Health, College of Health Sciences, Mizan-Tepi University, Ethiopia; E-mail: teklemariam36@gmail.com

Received Date: March 20, 2018; Accepted Date: April 25, 2018; Published Date: April 30, 2018

Citation: Teklemariam Ergat Yarinbab (2018) Postnatal Care Utilization and Its Determinants in Loma District, Southwest Ethiopia: A Community Based Cross Sectional Study. J Womens Health Gyn 5: 1-8.

\begin{abstract}
Background: The postnatal period is a critical phase in the lives of mothers and newborn babies. Most maternal and infant deaths occur during this time. However, this is the most neglected period for the provision of quality care. The aim of this study was to assess the status of postnatal care and its determinants among women who gave birth within one year preceding the study in Loma district, South West Ethiopia.
\end{abstract}

Methods: A community based cross sectional study was conducted in Loma district, South West Ethiopia. A multistage sampling technique was used. Data was collected using pre-tested questionnaires. Data was entered in to EpiData 3.1software and exported to SPSS version 20.0 for Bivariate and multivariate analysis.

Results: More than a-third of mothers utilized postnatal care services. Urban as place of residence (AOR=3.7, 95\% CI: 1.1, 13.2), being literate $(A O R=3.3 ; 95 \% C I: 1.3,8.5)$, being merchant ( $A O R=7.7 ; 95 \% C I: 1.4,42.4)$, and delivery at health post $(A O R=2.7 ; 95 \%$ CI: 1.0, 7.0) were found to be significantly associated with postnatal care service utilization.

Conclusion: Place of residence, place of delivery, educational status and occupational status were found to be determinants of postnatal care service utilization.

Keywords: Postnatal care utilization, determinants, Loma district, Ethiopia

Abbreviations: AOR: Adjusted Odds Ratio; ANC: Antenatal care; EDHS: Ethiopian Demographic Health Survey; FMOH: Federal Ministry of Health; HDA: Health Development Army; PNC: Postnatal care; RHB: Regional Health Bureau; SPSS: Statistical Package for Social Sciences; SNNPR: Southern Nations Nationalities and Peoples

(C)2018 The Authors. Published by the JScholar under the terms of the Creative Commons Attribution License http://creativecommons.org/licenses/by/3.0/, which permits unrestricted use, provided the original author and source are credited. 


\section{Introduction}

The Provision of Postnatal Care (PNC) services to the mother and their newborns within the first 42 days of life has been set up both with the objective to prevent and reduce maternal and neonatal deaths worldwide [1]. Care during this period is critical for the health and survival of both the mother and her newborn. Postnatal care is preeminently about the provision of a supportive environment in which a woman, her baby, and the wider family can begin their new life together. Many physiological and psychological changes that occur during the postnatal period determine their future well-being and health $[2,3]$.

Globally, more than half a million women die each year from complications of pregnancy and childbirth [4,5]. A large proportion of maternal and neonatal deaths occur during the first 48 hrs after delivery. Every year, four million infants die within their first month of life, representing nearly 40 percent of all deaths of under 5 age children [6]. In Ethiopia 61\% of maternal death takes place in the postpartum period and $58 \%$ of infant mortality rate occur in postnatal period $[4,7]$.

It is an incontrovertible fact that PNC services help to safeguard women from complications following delivery and provide important opportunities to assess the infant's development. Moreover, PNC services help to offer newborn care (e.g. counseling on breast feeding and Preventing Mother -toChild Transmission) and other services like immunization and family planning which are crucial for both the mother and the infant $[2,5,8]$.

Thus, the principal objectives of PNC services are to support the mother and her family in the transition to a new family constellation, prevent, early diagnose and treat complications of the mother and infant, refer the mother and infant for specialist care when necessary, counsel on baby care, support breastfeeding, counsel on maternal nutrition, and supplementation if necessary, counsel and provide contraception service, and immunize the infant [2].

Despite its importance, this period is generally the most neglected in developing countries and most mothers and new born babies do not receive postnatal care services from a skilled health care provider during the critical first few days after delivery $[1,2]$. Neonatal mortality of Ethiopia was 37 per 1000 live births which is the highest in sub Saharan African countries [9]. Accordingly, in Ethiopia, 61\% of maternal deaths and $58 \%$ of infant mortality rate takes place during this period. This problem is attributed by poor utilization of PNC and its low prevalence $[4,6]$.

Thus indentifying the factors deter PNC service utilization is crucial for countries, like Ethiopia, with alarmingly high maternal and neonatal mortality rates. Therefore, the purpose of this study was to assess the postnatal care utilization and its determinants in Loma district, southwest Ethiopia.

\section{Public Health Significance:}

The findings of this study elucidated the determinant factors of postnatal care service utilization in the community to Dawuro zone Health Department, Southern Nations Nationalities and Peoples Region (SNNPR) Health Bureau, Federal Ministry of Health (FMOH) and different organizations working in the area of Maternal and Child Health. Hence, along with other research findings, it would contribute in designing effective plans to alleviate determinant factors of postnatal care utilization. It could also enable different stake holders to realize the factors which deter the utilization of postnatal care among child bearing women in the population and give necessary support in the improvement of maternal health through proper utilization of postnatal care services.

Besides; the findings of the research would help political leaders, policy makers and higher experts in making right decisions for promotion of postnatal care utilization. Finally; it provides baseline evidence for researchers \& pave the way for further studies on postnatal care service utilization.

\section{Methods and Materials}

\section{Study area and period:}

The study was conducted in Loma district, SNNPR state, from Dec 08-28/2017. Loma district is located $471 \mathrm{KMs}$ to southwest of Addis Ababa, the capital of Ethiopia. Administratively, it is divided in to 40 kebeles (the smallest administrative units) with a population of 137,208 (projected from 2007 Census) in the year 2017 of which, 69,976 were females [10]. The estimated women population of reproductive age group was 31,969.

\section{Study design: \\ Community based cross-sectional study was con- ducted.}

\section{Sample Size determination :}

Sample size was calculated using single population proportion formula. The proportion of child bearing age women who used postnatal care (PNC) 37.2\% [11], 5\% margin of error, $95 \%$ confidence level, $5 \%$ non response rate and design effect of 2 was considered. Accordingly, the final sample size was calculated to be 694 . were included in the study.

\section{Sampling technique:}

A multi-stage sampling technique was used. Kebeles were primary sampling units (PSU) and Households were secondary sampling units (SSU). The district was classified in to four urban and 36 rural administrative units called kebeles'. Kebeles were stratified into urban and rural. Then $25 \%$ of the kebeles from each stratum were included in the study. Accordingly, 10 ( 1 urban and 9 rural) kebeles were selected randomly from the total kebeles in the district. For each selected kebeles allocation of women that gave birth within the last one year preceding the survey was done proportional to the number of eligible women in each kebele. Then the actual number of Households $(\mathrm{HH})$ with eligible mothers was taken from the records at health facilities. 
In addition, eligible women in each selected kebele was enumerated and reassured with health extension workers. Then those eligible HHs were given codes/numbers and sampling frame was formed. Finally, study HHs were selected by using simple random sampling from sampling frame and mother who gave birth within the last one year preceding the survey were interviewed and if more than one eligible woman dwells in same house, only one was included in study randomly.

The data was collected on socio-demographic and obstetric characteristics, use of ANC, place of current delivery and delivery assistance. Besides; data was collected on variables such as information on first visit of mother, timing of first visit for mothers who took PNC, place of visit for check up and type of personnel provided the check up.

\section{Data collection tool and procedure :}

Interviewer administered structured questionnaire was used to collect the data. The questionnaire was adapted from Ethiopian Demographic Health Survey (EDHS) 2011 [7]. Three BSc degree holders \& six diploma holder health professionals were participated in the data collection. Two supervisors were recruited from the adjacent woreda health office \& participated. One day orientation was given to the data collectors and supervisors on the data collection tools and procedures by the principal investigators.

\section{Data quality control:}

The questionnaires were translated from English into the local language (Dawurot'uwa) \& vice versa. A pre-test was conducted on $5 \%$ of the sample. Data collectors were trained on how to conduct the data collection. Daily supervision was held by field supervisors and the investigators. Data collectors were enabled to rectify incomplete and inconsistent data by supervisors at the time of data collection. Supervisors used to check all procedures and completeness of formats randomly. The collected data were rechecked before data entry.

\section{Data processing and Analysis:}

Data was analyzed by SPSS windows version 20. Frequencies and percentages of different variables were computed to summarize the data. Bivariate logistic regression model was fitted as a primary method of analysis. Based on the findings of bivariate analysis, variables having $\mathrm{p}<0.2$ were entered into multivariate logistic regression analysis using the forward LR method. Finally, $\mathrm{P}<0.05$ in multivariate analysis was used to declare determinants of postnatal care utilization.

\section{Definition of terms:}

\section{Early Postnatal care:}

Proportion of women who attended post natal care at least once during the early post-partum period (within 7 days after delivery).

\section{Skilled personnel:}

is a health professional that is trained in the skills needed to manage normal (uncomplicated) pregnancies, childbirth and the immediate postnatal period, and in the identification, management and referral of complications in women and newborns.

Skilled deliveries:Proportion of births attended by skilled health personals.

\section{Result}

\section{Socio-Demographic Characteristics :}

A total of 694 study participants were involved in the study with $97 \%$ of response rate. Majority $547(81.3 \%)$ of the respondents were residing in rural area. The mean age of the mothers was $30(+7)$ years. About $661(98.2 \%)$ of the respondents were married whereas 559(83.1\%) were protestant religion followers. Dawro, 641 (95.2\%), was the dominant ethnic group. Regarding their educational status and occupation of the study participants, $483(71.8 \%)$ and $573(85.1 \%)$ were literate and house wives, respectively. Majority, 611(90.8\%), of the study participants had more than four family members (Table $1)$.

\section{Maternal health service utilization and Obstetric Charac-} teristics :

The study revealed that the level of ANC and PNC service utilizations were $296(44.0 \%)$ and $247(36.7 \%)$, respectively. Besides, slightly more than half, 341(50.7\%), of study participants had history of pregnancy three to five times. About one-fourth (25.2\%) of the mothers had attended skilled delivery services, while $186(27.6 \%)$ of the mothers gave their last birth at home (Table 2\&3). 


\begin{tabular}{|c|c|c|}
\hline Variables & Categories & No (\%) \\
\hline \multirow[t]{3}{*}{ Age of mother } & $15-24$ & $147(21.8)$ \\
\hline & $25-34$ & $307(45.6)$ \\
\hline & $\geq 35$ & $219(32.5)$ \\
\hline \multirow{2}{*}{$\begin{array}{l}\text { Educational status of } \\
\text { mother }\end{array}$} & Illiterate & $190(28.2)$ \\
\hline & Literate & $483(71.8)$ \\
\hline \multirow{4}{*}{$\begin{array}{l}\text { Occupational status of } \\
\text { mother }\end{array}$} & Gov. Employee & $39(5.8)$ \\
\hline & Farmer & $7(1.0)$ \\
\hline & merchant & $54(8.0)$ \\
\hline & House wife & $573(85.1)$ \\
\hline \multirow[t]{2}{*}{ Residence } & Urban & $126(18.7)$ \\
\hline & Rural & $547(81.3)$ \\
\hline \multirow[t]{3}{*}{ Religion } & Orthodox & $105(1.6)$ \\
\hline & Protestant & $559(83.1)$ \\
\hline & Others & $9(1.3)$ \\
\hline \multirow[t]{3}{*}{ Ethnicity of mother } & Dawro & $641(95.2)$ \\
\hline & Wolayta & $18(2.7)$ \\
\hline & Other & $14(2)$ \\
\hline \multirow[t]{2}{*}{ Husbands' education } & Illiterate & $300(45.4)$ \\
\hline & Literate & $361(54.6)$ \\
\hline \multirow[t]{4}{*}{ Husbands' occupation } & Farmer & $518(77.0)$ \\
\hline & Employee & $69(10.3)$ \\
\hline & Merchant & $57(8.5)$ \\
\hline & Others & $17(2.5)$ \\
\hline \multirow{4}{*}{$\begin{array}{l}\text { HH monthly Income } \\
\text { (ETB) }\end{array}$} & $\leq 500$ & $274(40.7)$ \\
\hline & $501-1000$ & $274(40.7)$ \\
\hline & $1001-1500$ & $93(13.8)$ \\
\hline & $\geq 1501$ & $32(4.7)$ \\
\hline \multirow[t]{2}{*}{ Distance to HF } & $\leq 2$ hours & $330(49.0)$ \\
\hline & $>2$ hours & $343(51.0)$ \\
\hline \multirow[t]{3}{*}{ HH size } & $\leq 3$ & $62(9.2)$ \\
\hline & $4-6$ & $500(74.3)$ \\
\hline & $>6$ & $111(16.5)$ \\
\hline \multirow{3}{*}{$\begin{array}{l}\text { Decision on maternal } \\
\text { health services }\end{array}$} & Self & $204(30.3)$ \\
\hline & jointly & $328(48.7)$ \\
\hline & Husband & $141(21.0)$ \\
\hline \multirow[t]{2}{*}{ Marital status } & Married & $661(98.2)$ \\
\hline & Divorced & $12(1.7)$ \\
\hline
\end{tabular}

\begin{tabular}{|c|c|c|}
\hline Variables & Categories & No $(\%)$ \\
\hline \multirow{2}{*}{$\begin{array}{l}\text { ANC during last } \\
\text { pregnancy }\end{array}$} & Yes & $296(44.0)$ \\
\hline & No & $377(56.0)$ \\
\hline \multirow[t]{3}{*}{ Parity } & $1-2$ & $266(39.5)$ \\
\hline & $3-5$ & $341(50.9)$ \\
\hline & $>5$ & $66(9.8)$ \\
\hline \multirow[t]{4}{*}{ Place of ANC } & Hospital & $90(13.4)$ \\
\hline & Health Center & $144(21.4)$ \\
\hline & Health Post & $29(4.3)$ \\
\hline & Home & $33(4.9)$ \\
\hline \multirow[t]{3}{*}{ Number of ANC } & Four and above & $39(5.8)$ \\
\hline & Two to three & $182(27.0)$ \\
\hline & One & $75(11.1)$ \\
\hline \multirow[t]{3}{*}{ ANC providers } & $\begin{array}{l}\text { Doctor/nurse/mid- } \\
\text { wife }\end{array}$ & $227(33.7)$ \\
\hline & $\begin{array}{l}\text { Health extension } \\
\text { worker }\end{array}$ & $34(5.1)$ \\
\hline & $\begin{array}{l}\text { Traditional birth at- } \\
\text { tendants }\end{array}$ & $35(5.2)$ \\
\hline \multirow[t]{4}{*}{ Place of delivery } & Hospital & $65(9.7)$ \\
\hline & Health Center & $105(15.6)$ \\
\hline & Health Post & $317(47.1)$ \\
\hline & Home & $186(27.6)$ \\
\hline \multirow{3}{*}{$\begin{array}{l}\text { Mode of last de- } \\
\text { livery }\end{array}$} & Cesarean section & $11(1.6)$ \\
\hline & Instrumental delivery & $51(7.6)$ \\
\hline & spontaneous vaginal & $611(90.8)$ \\
\hline \multirow[t]{2}{*}{ Number of PNC } & 2-3 times & $166(24.7)$ \\
\hline & 4 and above & $15(2.2)$ \\
\hline
\end{tabular}

Table 2: Obstetric history of maternal health service in Loma district, Ethiopia, 2017

Table 1: Socio-economic and demographic characteristics of study participants in Loma district, Ethiopia, 2017 


\begin{tabular}{|c|c|c|}
\hline Variables & Categories & No $(\%)$ \\
\hline \multirow{3}{*}{$\begin{array}{l}\text { Delivery assis- } \\
\text { tance }\end{array}$} & Doctor/nurse/midwife & $165(24.5)$ \\
\hline & $\begin{array}{l}\begin{array}{l}\text { Health extension } \\
\text { workers }\end{array} \\
\end{array}$ & $331(49.2)$ \\
\hline & $\begin{array}{l}\text { Traditional birth at- } \\
\text { tendants }\end{array}$ & $177(26.30)$ \\
\hline \multirow[t]{2}{*}{ Check at HFs } & Yes & $139(20.7)$ \\
\hline & No & $54(79.3)$ \\
\hline \multirow{2}{*}{$\begin{array}{l}\text { Time of first check } \\
\text { up at HFs }\end{array}$} & Less than 4 hours & $6(.9)$ \\
\hline & 4-23 hours & $133(19.8)$ \\
\hline \multirow[t]{4}{*}{ Duration at HFs } & Less than 2 hours & $6(.9)$ \\
\hline & 2-5 hours & $3(.4)$ \\
\hline & Half day & $127(18.9)$ \\
\hline & 12-24 hours & $3(.4)$ \\
\hline \multirow[t]{2}{*}{ PNC } & Yes & $247(36.7)$ \\
\hline & No & $426(63.3)$ \\
\hline \multirow[t]{4}{*}{ Place of PNC } & Home & $74(11.0)$ \\
\hline & Health post & $108(16.0)$ \\
\hline & Health center & $61(9,1)$ \\
\hline & Hospital & $4(0.6)$ \\
\hline \multirow[t]{3}{*}{ PNC provider } & Doctor/nurse/midwife & $82(12.2)$ \\
\hline & $\begin{array}{l}\begin{array}{l}\text { Health extension } \\
\text { workers }\end{array} \\
\end{array}$ & $160(23.8)$ \\
\hline & $\begin{array}{l}\text { Traditional birth at- } \\
\text { tendants }\end{array}$ & $5(0.7)$ \\
\hline \multirow[t]{4}{*}{ Service in PNC } & EPI & $461(68)$ \\
\hline & $\begin{array}{l}\text { Nutritional counseling } \\
\text { of mothers and new- } \\
\text { born }\end{array}$ & $272(40.4)$ \\
\hline & Family planning & $175(26.0)$ \\
\hline & Others & $87(12.9)$ \\
\hline \multirow{3}{*}{$\begin{array}{l}\text { Duration of first } \\
\text { PNC }\end{array}$} & $0-24$ hours & $15(2.2)$ \\
\hline & 2-7 days & $34(5.1)$ \\
\hline & 8-42 days & $198(29.4)$ \\
\hline
\end{tabular}

Table 3: Maternal health service utilization of women in Loma district, Ethiopia, 2017

Knowledge of Women on Complication Related to Pregnancy and source of health information

Majority, 621(92.3\%), of the mothers had knowledge about danger sign that could occur during pregnancy /labor. Large number of women had knowledge of complications related to delivery and labor, of which 541(80.4\%) mentioned prolonged labor. Besides, 338(50.2\%) of mothers got information from health professionals including health extension workers whereas $227(33.7 \%)$ of them reported to have got through Health Development Army (HAD) network (Table 4).

\begin{tabular}{|c|c|c|}
\hline Variables & Categories & $\mathrm{N}(\%)$ \\
\hline \multirow{3}{*}{$\begin{array}{l}\text { Complication of } \\
\text { pregnancy and } \\
\text { delivery }\end{array}$} & Yes & $621(92.3)$ \\
\hline & No & $40(5.9)$ \\
\hline & I don't remember & $12(1.8)$ \\
\hline \multirow[t]{3}{*}{ Complication } & $\begin{array}{l}\text { Excessive vaginal bleed- } \\
\text { ing }\end{array}$ & $96(14.3)$ \\
\hline & Prolonged labor & $541(80.4)$ \\
\hline & retained placenta & $17(2.5)$ \\
\hline \multirow{6}{*}{$\begin{array}{l}\text { Reason for non } \\
\text { use of PNC }\end{array}$} & Cost too much & $6(0.9)$ \\
\hline & Facility not open & $28(4.2)$ \\
\hline & $\begin{array}{l}\text { Facility too far/no trans- } \\
\text { portation }\end{array}$ & $214(31.8)$ \\
\hline & Poor quality service & $108(16.0)$ \\
\hline & $\begin{array}{l}\text { Husband/family did not } \\
\text { allow }\end{array}$ & $49(7.3)$ \\
\hline & Not necessary & $3(0.4)$ \\
\hline \multirow[t]{2}{*}{ Knows risk } & Yes & $473(70.3)$ \\
\hline & No & $200(29.7)$ \\
\hline \multirow[t]{3}{*}{ Risk response } & Pregnancy related disease & $228(33.9)$ \\
\hline & Maternal death & $201(29.9)$ \\
\hline & Fetal death & $44(6.5)$ \\
\hline \multirow{4}{*}{$\begin{array}{l}\text { Source of health } \\
\text { message }\end{array}$} & Mass media & $103(15.3)$ \\
\hline & $\begin{array}{l}\text { Health professionals } \\
\text { including HEWs }\end{array}$ & $338(50.2)$ \\
\hline & Through HDA network & $227(33.7)$ \\
\hline & TBAs & $5(0.7)$ \\
\hline
\end{tabular}

Table 4: Knowledge of mothers on danger sign, complications related to pregnancy and other maternal health services in Loma district, Ethiopia, 2017. 


\section{Determinants of Postnatal Care Utilization}

The multivariate logistic regression analysis revealed place of residence, educational status, occupational status and place of delivery were significantly associated with postnatal care utilization.

Accordingly, women who gave birth at health institutions were nearly three times (AOR=2.7, 95\% CI: 1.1, 7.0) more likely to attend postnatal care services as compared to women who delivered at home. Besides, women who were literate were three times $(\mathrm{AOR}=3.3$; 95\% CI: $1.3,8.5)$ more likely to utilize postnatal care service as compared to those women who were illiterate. Moreover, those women who resided in urban setup were nearly four times (AOR=3.7; 95\% CI: 1.1, 13.2) more likely to attend postnatal care services compared to those women's who resided in rural community (Table 5).

\begin{tabular}{|c|c|c|c|}
\hline \multirow[t]{2}{*}{ Variables } & \multicolumn{2}{|c|}{ PNC utilization } & \multirow[b]{2}{*}{$\begin{array}{l}\text { AOR }(95 \% \\
\text { CI) }\end{array}$} \\
\hline & Yes (\%) & No (\%) & \\
\hline \multicolumn{4}{|l|}{ Residence } \\
\hline Urban & $77(61.6)$ & $49(38.9)$ & $\begin{array}{l}3.72(1.1 \\
13.20)^{* *}\end{array}$ \\
\hline Rural & $160(30.1)$ & $377(68.9)$ & 1.00 \\
\hline \multicolumn{4}{|l|}{$\begin{array}{l}\text { Education of } \\
\text { mothers }\end{array}$} \\
\hline Literate & $114(76)$ & $76(40)$ & $\begin{array}{l}3.34(1.32 \\
8.47)^{\star *}\end{array}$ \\
\hline $\begin{array}{l}\text { Read and write/ } \\
\text { informal }\end{array}$ & $80(37.6)$ & $133(62.4)$ & $\begin{array}{l}1.53(0.73, \\
3.19)\end{array}$ \\
\hline Illiterate & $53(19.6)$ & $217(80.4)$ & 1.00 \\
\hline \multicolumn{4}{|l|}{$\begin{array}{l}\text { Occupation of } \\
\text { mothers }\end{array}$} \\
\hline Gov employee & $24(61.5)$ & $15(7.4)$ & $\begin{array}{l}1.82(0.37 \\
8.9)\end{array}$ \\
\hline Farmer & $4(57.1)$ & $3(42.9)$ & 0.000 \\
\hline Merchant & $30(55.5)$ & $24(44.5)$ & $\begin{array}{l}7.67(1.4 \\
42.4)^{\star *}\end{array}$ \\
\hline House wife & 189(32.9) & $384(94.1)$ & 1.00 \\
\hline \multicolumn{4}{|l|}{ Number of ANC } \\
\hline Four and above & $26(66)$ & $13(34)$ & $.12(.038, .43)$ \\
\hline Two to three & $116(63.7)$ & $66(35.3)$ & $.21(.088, .50)$ \\
\hline one & $26(34)$ & $49(66)$ & 1.00 \\
\hline \multicolumn{4}{|l|}{ ANC Provider } \\
\hline $\begin{array}{l}\text { Doctor/nurse/ } \\
\text { midwife }\end{array}$ & $151(66.5)$ & $76(33.5)$ & $\begin{array}{l}.312(.72 \\
1.36)\end{array}$ \\
\hline $\begin{array}{l}\text { Health extension } \\
\text { workers }\end{array}$ & $12(35.3)$ & $22(64.7)$ & $\begin{array}{l}1.152(.20, \\
6.53)\end{array}$ \\
\hline $\begin{array}{l}\text { Traditional birth } \\
\text { attendants }\end{array}$ & $5(14.3)$ & $30(35.7)$ & 1.00 \\
\hline
\end{tabular}

\begin{tabular}{|c|c|c|c|}
\hline \multicolumn{4}{|l|}{ Place of Delivery } \\
\hline Hospital & $44(68)$ & $21(32)$ & $0.9(.3,3.1)$ \\
\hline Health Center & $54(51.4)$ & $51(48.6)$ & $\begin{array}{l}1.658(0.57 \\
4.83)\end{array}$ \\
\hline Health Post & $100(31.5)$ & $217(68.5)$ & $\begin{array}{l}2.25(1.1,7.0) \\
\star *\end{array}$ \\
\hline Home & $49(26.3)$ & $137(73.7)$ & 1.00 \\
\hline \multicolumn{4}{|l|}{$\begin{array}{l}\text { Delivery assis- } \\
\text { tance }\end{array}$} \\
\hline $\begin{array}{l}\text { Doctor/nurse/ } \\
\text { midwife }\end{array}$ & $125(75.7)$ & $40(24.3)$ & $\begin{array}{l}0.64(.116, \\
3.55)\end{array}$ \\
\hline $\begin{array}{l}\text { Health extension } \\
\text { workers }\end{array}$ & $96(29)$ & $235(71)$ & $\begin{array}{l}4.69(.907, \\
24.32)\end{array}$ \\
\hline $\begin{array}{l}\text { Traditional birth } \\
\text { attendants }\end{array}$ & $26(15)$ & 151(85) & 1.00 \\
\hline \multicolumn{4}{|l|}{ Distance to HF } \\
\hline $\begin{array}{l}\text { Less than or } \\
\text { equal } 2 \text { hours }\end{array}$ & $155(66.5)$ & $175(33.5)$ & $\begin{array}{l}1.78(.927, \\
3.42)\end{array}$ \\
\hline $\begin{array}{l}\text { Greater than } 2 \\
\text { hours }\end{array}$ & $92(26.8)$ & $251(73.2)$ & 1.00 \\
\hline
\end{tabular}

$1.00=$ Referent category, ${ }^{*}$ statistically associated at p-value $<0.05$

Table 5: Determinants of postnatal care utilization in Loma district, Ethiopia, 2017

\section{Discussion}

This study had focused on the utilization of postnatal care and its determinants. The study revealed that the proportion of postnatal care service utilization was $36.7 \%$. This finding is lower than the findings of studies conducted in Cambodia, Nepal and Ethiopia [3, 12, 13]. The difference might happened due to the fact that majority of the participants were rural settings; who might have less access to health facilities with integrated maternal health services. In contrast, this finding is higher than the overall national average of EDHS finding of 2011 [7] and other study done in Jabitena district of Amhara Region, Ethiopia [14]. This may be attributed to the time difference that there could be improvement in accessing and utilizing health care service through time.

Literate mothers showed better utilization of postnatal care services as compared to illiterate women. This result is similar with findings from studies conducted in Ethiopia, Indonesia, and India $[14,15,16]$. This could be explained by the fact that education has a valuable input in enhancing female autonomy and help women develop greater confidence and capability to make decisions about their own health. Thus, literate women seek out higher quality health services and have greater ability to use health care inputs that offer better health outcomes. 
Besides, urban mothers were 3.7 times more likely to receive PNC services than rural mothers. This was in line with the evidence from EDHS 2011 [7], Cambodia [3] and Nepal [12] in which urban mothers were more likely to receive PNC services than rural mothers from both health professionals and non-health professionals. This might be due to the fact that urban women may have information from different sources on PNC services or because of the availability of a good number of health institutions in urban areas.

With regard to influence of mother's occupation on postnatal care services, mothers who were housewives were less likely to attend postnatal care services as compared to those who were merchants. It is reasonable to assume that women who entirely own household responsibility as housewife may be unable to attend postnatal care services due to their tiresome indoor works; which may limit them from seeking maternal health care services. Accordingly, mothers who were merchants were more likely to be aware of the benefits of obtaining postnatal care services through different media such as television and newspapers than their counterparts that most of the time housewives stay at home with family responsibility. This finding suggests that there is a need to provide postnatal care services through alternative community based approaches to address these groups.

Mothers who had delivered their last baby in health institution utilized postnatal care services more likely when compared with those who delivered at home. This finding is similar with study findings from India, Cambodia, Nepal and Ethiopia $[17,3,12,13]$. This may be attributed to the fact that women who gave their last birth in health institution have greater opportunity to get exposed to health education related to PNC services at the time of delivery and thus get access to learn about the types, benefits and availabilities of PNC services during their stay in the health institutions.

\section{Conclusion}

The level of postnatal care service utilizations was found to be only a-third. Postnatal care utilization was positively associated with place of residence, educational status, occupational status and place of delivery. Accordingly; living in rural area, low literacy status, engaged in laborious government office works and home delivery were found to be determinants of postnatal care utilization.

\section{Recommendation}

Federal Ministry of Health in collaboration with Ministry of Education should work on better access of women education. Regional Health Bureaus should focus their intervention on improvement of institutional delivery. Besides; Zonal and District Health Offices in collaboration with other stakeholders should work hard to improve the postnatal care utilization of women living in rural area. Further study should be conducted on the partners' influence and health institution based factors on postnatal care utilization to have full picture of the determinant factors.

\section{Ethical approval and consent to partici- paten}

Before the actual data collection; the proposal was presented to Jimma University, Department of Epidemiology, and then ethical clearance letter was obtained. The participants were well informed about the purposes of the study, and oral consents were obtained accordingly. The participants' rights to refuse or withdraw from participating in the study and confidentiality issues were considered.

\section{Authors' contribution}

Both TE and WC took the role from conception to design, wrote down the proposal, supervised the data collection process, conducted the final analysis and report writing, and drafted the manuscript. Both authors critically reviewed and approved the final manuscript.

\section{Acknowledgments}

First of all, our deepest gratitude and appreciation goes to Department of Epidemiology; College of Health Sciences, Jimma University. We would also like to extend our gratitude to Loma district health office staffs and the health centers staffs for their cooperation in the data collection. Finally, our great appreciation goes to the data collectors and supervisors who participated in the study. 


\section{References}

1) WHO (2013) recommendations on Postnatal care of the mother and newborn October Geneva, Switzerland

2) WHO (2013) Technical consultation on postpartum and postnatal care, Geneva, Switzerland

3) Net Kim e.tal (2013) Early Postnatal Care and its Determinants in Cambodia: Further Analysis of the Cambodia Demographic and Health Survey. Phnom Penh, Cambodia: National Institute of Statistics, Ministry of Planning and Directorate General for Health, Ministry of Health.

4) Abdella A (2010) Maternal mortality trend in Ethiopia. Ethiopian Journal of Health Development 115-212.

5) World Health Organization (WHO), UNICEF, UNFPA, the World Bank. Maternal mortality in 2005: estimates developed by WHO, UNICEF, UNFPA and The World Bank. Geneva, WHO, 2008.

6) Lawn JE, Cousens S, Zupan J (2005) 4 Million Neonatal Deaths: When? Where? Why? Lancet 365: 891-900.

7) Central Statistical Authority and ICF International: Ethiopia Demographic and Health Survey 2011. Addis Ababa, Ethiopia and Calverton, Maryland, USA: Central Statistical Agency; 2012.

8) WHO (1998) Safe motherhood: Postpartum care of the mother and newborn a practical guide. Geneva 50-51.

9) (2012) Progress Report on Millennium Development Goals Development, Addis Ababa, Ethiopia

10) Central Statistical Agency of Ethiopia: Census report of 2007. Addis Ababa, Ethiopia

11) Regassa N (2011) Antenatal and postnatal care service utilization in Southern Ethiopia: A population-based study. African Health Sciences 390-397.

12) (2011) Factors associated with the utilization of postnatal care services among the mothers of Nepal: Analysis of Nepal Demographic and Health Survey.

13) Asfawosen Aregay, Mussie Alemayehu, Huruy Assefa, Wondeweson Terefe (2014) Factors Associated with Maternal Health Care Services in Enderta District, Tigray, Northern Ethiopia: A Cross Sectional Study: American Journal of Nursing Science. 3: 117-125.

14) Yinager Gebeyehu Workineh, Desta Aregawi Hailu (2014) Factors Affecting Utilization of Postnatal Care Service in Amhara Region, Jabitena District, Ethiopia: Science Journal of Public Health 2: 169-176.

15) Titaley CR., Dibley MJ., \& Roberts CL (2009) Factors associated with non-utilization of postnatal care services in Indonesia. J Epidemiol Community Health 63:827-831.

16) Digambar A. \& Sahoo H (2012) Factors influencing utilization of maternal health care services in uttarakhand, India: EthoMed 209216

17) Jat R., Nawi Ng, and Sebastian S (2012) Factors affecting the use of maternal health services: Madhya Pradesh state in India. International Journal for Equity in Health 7-9.

\footnotetext{
Submit your manuscript to a JScholar journal and benefit from:

- Convenient online submission

q Rigorous peer review

- Immediate publication on acceptance

q Open access: articles freely available online

9 High visibility within the field

- Better discount for your subsequent articles Submit your manuscript at http://www.jscholaronline.org/submit-manuscript.php
} 